\title{
Immunoporosis: Immunology of Osteoporosis-Role of T Cells
}

\author{
Rupesh K. Srivastava ${ }^{1,2 *}$, Hamid Y. Dar ${ }^{1}$ and Pradyumna K. Mishra ${ }^{3}$ \\ ${ }^{1}$ Department of Zoology, School of Biological Sciences, Dr. Hari Singh Gour University, Sagar, India, \\ ${ }^{2}$ Department of Biotechnology, All India Institute of Medical Sciences (AIIMS), New Delhi, India, ${ }^{3}$ Department \\ of Molecular Biology, ICMR-National Institute for Research in Environmental Health, Bhopal, India
}

\section{OPEN ACCESS}

Edited by:

Amit Awasthi,

Translational Health Science and Technology Institute, India

Reviewed by:

Thomas Ciucci,

National Cancer Institute (NIH),

United States

Xing Chang,

Shanghai Institutes for Biological Sciences (CAS), China

*Correspondence:

Rupesh K. Srivastava

rksrivastava@aiims.edu,

rupesh_srivastava13@yahoo.co.in

Specialty section:

This article was submitted

to T Cell Biology,

a section of the journal

Frontiers in Immunology

Received: 05 December 2017

Accepted: 16 March 2018

Published: 05 April 2018

Citation:

Srivastava RK, Dar HY and Mishra PK (2018) Immunoporosis: Immunology of Osteoporosis - Role of T Cells.

Front. Immunol. 9:657. doi: 10.3389/fimmu.2018.00657
The role of immune system in various bone pathologies, such as osteoporosis, osteoarthritis, and rheumatoid arthritis is now well established. This had led to the emergence of a modern field of systems biology called as osteoimmunology, an integrated research between fields of immunology and bone biology under one umbrella. Osteoporosis is one of the most common inflammatory bone loss condition with more than 200 million individuals affected worldwide. T helper (Th) cells along with various other immune cells are major players involved in bone homeostasis. In the present review, we specifically discuss the role of various defined $T$ lymphocyte subsets (Th cells comprising Th1, Th2, Th9, Th17, Th22, regulatory $T$ cells, follicular helper $T$ cells, natural killer $T$ cells, $\gamma \delta \mathrm{T}$ cells, and CD8 ${ }^{+} \mathrm{T}$ cells) in the pathophysiology of osteoporosis. The study of the specific role of immune system in osteoporosis has now been proposed by our group as "immunoporosis: the immunology of osteoporosis" with special emphasis on the role of various subsets of T lymphocytes. The establishment of this new field had been need of the hour due to the emergence of novel roles of various T cell lymphocytes in accelerated bone loss observed during osteoporosis. Activated T cells either directly or indirectly through the secretion of various cytokines and factors modulate bone health and thereby regulate bone remodeling. Several studies have summarized the role of inflammation in pathogenesis of osteoporosis but very few reports had delineated the precise role of various $T$ cell subsets in the pathobiology of osteoporosis. The present review thus for the first time clearly highlights and summarizes the role of various $T$ lymphocytes in the development and pathophysiology of osteoporosis, giving birth to a new field of biology termed as "immunoporosis". This novel field will thus provide an overview of the nexus between the cellular components of both bone and immune systems, responsible for the observed bone loss in osteoporosis. A molecular insight into the upcoming and novel field of immunoporosis would thus leads to development of innovative approaches for the prevention and treatment of osteoporosis.

\section{Keywords: immunoporosis, osteoimmunology, bone loss, T lymphocytes, osteoporosis}

\footnotetext{
Abbreviations: IFN, interferon; MCSF, macrophage colony-stimulating factor; NF- $\kappa \mathrm{B}$, nuclear factor $\kappa \mathrm{B}$; $\mathrm{BM}$, bone marrow; $\mathrm{T}_{\mathrm{FH}}$, follicular helper T; NKT cells, natural killer T cells; OPG, osteoprotegerin; TRAF, TNF receptor-associated factor; TRAF-6, TNF receptor-associated factor 6; RANK, receptor activator of NF- $\kappa B$; RANKL, RANK ligand; MCP-1, monocyte chemoattractant protein-1; TGF- $\beta$, transforming growth factor beta; BMD, bone mineral density; TCR, T cell receptor; Th, T-helper; DC, dendritic cell; RA, rheumatoid arthritis; OA, Osteoarthritis.
} 


\section{INTRODUCTION}

Osteoporosis leads to enhanced rate of fractures and fragility of bones observed in both men and women. It has been estimated that more than $50 \%$ of women and $30 \%$ of men over the age of 50 years are susceptible for such fractures and bone loss (1). One-third of females and one-fourth of males will be suffering from osteoporosis leading to significant rise in mortality (20-30\% associated with first hip fracture) and morbidity (2). Osteoporosis accounts for more than nine million of fractures annually (2). According to the latest International Osteoporosis Foundation report (3), it is estimated that by 2040 the number of osteoporotic patients above age of 50 years will double worldwide from that of 2010 figures of 158 million $(3,4)$. It has been estimated that by the end of 2025 the economic burden of osteoporosis will reach $\$ 25.3$ billion in the USA alone $(5,6)$.

Due to their common developmental niche, both the bone and immune systems work as a close knit functional unit (osteoimmune system), thereby leading to permanent interactions at various anatomical and vascular sites (7). This interaction of immune and skeletal system has now made it clear to the scientific fraternity that there do exist a nexus between these duo-systems. This intricate relationship between bone and immune systems has been fascinating scientists since the early 1970s, paving path for birth of a dedicated field of modern biology called as "osteoimmunology" (8). Dysregulation of immune system has already been related with initiation of different inflammatory autoimmune diseases leading to adverse effects on bone integrity (9). This affects the bone either in a localized way as in case of rheumatoid arthritis (RA) or via modulating bone metabolism which regulates key bone cell activities including differentiation. In other cases, immune cells induce changes in key factors or functional components of bone mass regulators, thereby affecting bone health. However, still the interaction between bone and immune system which is not unidirectional is largely unexplored. Indeed, during the recent past it has been observed in various studies that $\mathrm{T}$ lymphocytes play an important role in the process of bone remodeling (10).

Bone remodeling is a dynamic equilibrium occurring as a result of interaction between bone cells and bone marrow (BM) cells. Therefore, the lymphocytes residing within the BM form an important component for such process to occur. $\mathrm{T}$ cells which account for $\sim 5 \%$ of total BM cells are found efficiently in both stromal and parenchymal parts of BM (11). T cells are represented by both $\mathrm{CD} 4^{+} \mathrm{T}$ and $\mathrm{CD} 8^{+} \mathrm{T}$ cell populations. $\mathrm{CD} 4^{+}$ $\mathrm{T}$ cells have a vital role in the function and maintenance of the immune system by helping $\mathrm{B}$ cells to enhance production of antibodies along with orchestrating $\mathrm{CD} 8^{+} \mathrm{T}$ cells and other immune cell functions (12). Naive $\mathrm{CD} 4^{+} \mathrm{T}$ cells differentiate into Th1, Th2, Th9, Th17, Th22, regulatory $\mathrm{T}$ (Treg) and follicular helper $\mathrm{T}\left(\mathrm{T}_{\mathrm{FH}}\right)$ depending upon their respective environmental stimuli (13-16). Th17 cells are primarily responsible for initiating and stimulating bone resorption (osteoclastogenesis) $(17,18)$, while Treg cells are peculiarly associated with inhibition of bone resorption (18-21). Strikingly, not all $\mathrm{T}$ cells are osteoclastogenic, as $\mathrm{CD}^{+} \mathrm{T}$ cells have recently been reported with bone protecting functions, thereby inhibiting bone loss. $\mathrm{CD} 8^{+} \mathrm{T}$ cells inhibit the process of osteoclastogenesis via secretion of various soluble factors, such as osteoprotegerin (OPG) (18) and interferon (IFN)- $\gamma$ for regulating bone mass (22). Also, several studies have postulated that $\mathrm{T}$ cells may simultaneously function as an activator of bone formation (osteoblastogenesis), as they are associated with activation of Wnt signaling pathway in osteoblastic cells (18). In the present review, we will specially focus on the role of various subsets of $\mathrm{T}$ lymphocytes, their plasticity, and related unraveled opportunities for future clinical implications in various bone pathologies, with special emphasis on osteoporosis, i.e., "immunoporosis".

\section{BONE CELLS}

Bone, a dynamic organ undergoes continuous remodeling throughout the life of an organism. This task of bone remodeling is meticulously achieved via the coordinated synergism between three different types of bone cells, viz. osteoclasts (bone eating cells), osteoblasts (bone forming cells) and osteocytes (bone deposition and resorption cells). Osteoblasts originate from mesenchymal stem cells (MSCs) in the BM which also gives rise to chondrocytes, myocytes and adipocytes. Runt-related transcription factor 2 and its target gene the $\mathrm{Sp} 7$ transcription factor (known as osterix) are primarily responsible for differentiation of MSCs into osteoblasts (23). In addition, Wnt signaling also plays an important role in the differentiation of osteoblasts (24). Osteocytes are produced as a result of matrix calcification of osteoblasts under the influence of enzyme alkaline phosphatase. Any mechanical strain on the bones is progressed by osteocytes by sending signals through cellular processes (canaliculis) to interconnecting osteocytes and also to osteoblasts on surface of bones (25). Osteoclasts are multi-nuclear bone cells which are primarily responsible for bone resorption. They get differentiated from monocytic cell lineages like dendritic cells, macrophages, granulocytes, and microglia. Macrophage colony-stimulating factor (MCSF) is an essential factor required for proliferation and survival of osteoclasts, along with RANK ligand (RANKL) acting via its coupling molecule TNF receptor-associated factor 6 (TRAF-6) which leads to their final induction and differentiation (23). For maintaining bone integrity, a dynamic equilibrium is essential between bone forming osteoblasts and bone resorbing osteoclasts. Osteal macrophages (Osteomacs) on the other hand represent a special population of macrophage residing in bony tissues. The term "Osteomacs" was given by Australian researcher Allison Pettit. These are stellate shaped cells and are approximately one-sixth of the cells found in BM, giving rise to a complex networking system (26). They usually get originated from $\mathrm{CD} 68^{+}$cell types of macrophage origin (27). Osteomacs are responsible for full functional differentiation and mineralization of osteoblasts during in vitro cultures and forms canopy at the site of bone remodeling during in vivo conditions. It has been observed that any reduction/alteration of macrophages leads to total loss of endosteal osteomacs and respective osteoblasts, thereby concluding that osteomacs have an important role in maintenance of osteoblast maturity $(12,26,28-30)$. 


\section{BONE REMODELING}

Bone remodeling is a dynamic equilibrium resultant of various physiological/mechanical stress accompanied with differential functional adaptations of the bone (31). This dynamicity results in multi-mode interactions between bone resorbing osteoclasts and bone forming osteoblasts $(32,33)$. Remodeling leads to restoration of bone micro-damages and bone integrity via the balancing act in the release of calcium and phosphorus in host. In fact, remodeling corroborates important relationship between bone formation (osteoblastogenesis) and bone resorption (osteoclastogenesis) (Figure 1), regulated at various phases due to impact of immune system on bone cells, neuro-endocrine relationship with bone or a direct interface of osteoclasts and osteoblasts. Bone remodeling comprises of following fourstep, viz. activation, resorption, reversal and formation (34). Remodeling signals that arise from direct or indirect signals, due to action of hormones [estrogen and parathyroid hormone $(\mathrm{PTH})]$ or structural damage leads to initiation of activation phase. This step is marked by higher apoptotic rate of osteocytes and increased osteoclastogenesis which enhances bone damage (35). The decreasing levels of transforming growth factor beta (TGF- $\beta$ ) resulting from osteoclast apoptosis enhances osteoclastogenesis many folds (36). During activation phase, osteoclast precursor activation occurs as a result of increased activity of protein kinase (C/A) and calcium signaling which is mainly responsible for bone resorption (37). This phase is followed by resorption phase, where osteoclast precursors are recruited by osteoblasts at the site of bone remodeling due to various endocrine signaling or by osteocytes. During this phase, osteoblasts overexpress monocyte chemoattractant protein-1 leading to upregulation of RANKL-induced osteoclastogenesis (38). RANKL is mainly responsible for differentiation and proliferation of osteoclast precursors into multinucleated osteoclasts, thereby enhancing life of mature osteoclasts (38). This results in emergence of an isolated environment called as "sealed zone" due to continuous adhesion of osteoclasts to integrin-binding sites $\left(\alpha_{v} \beta_{3}\right.$ integrin molecules) on the bone surface (39). The overall result is formation of Howship's resorption lacunae with increased hydrogen ion concentration (acidic environment) facilitating dissolution of mineralized and organic components of bone (40). The accumulation of cathepsin K enzyme further enhances this rate of bone resorption (41).

Macrophages enhance the expression of osteopontin that leads to deposition of collagen matrix within Howship's lacunae (42). Next, the bone surface is prepared for bone formation by

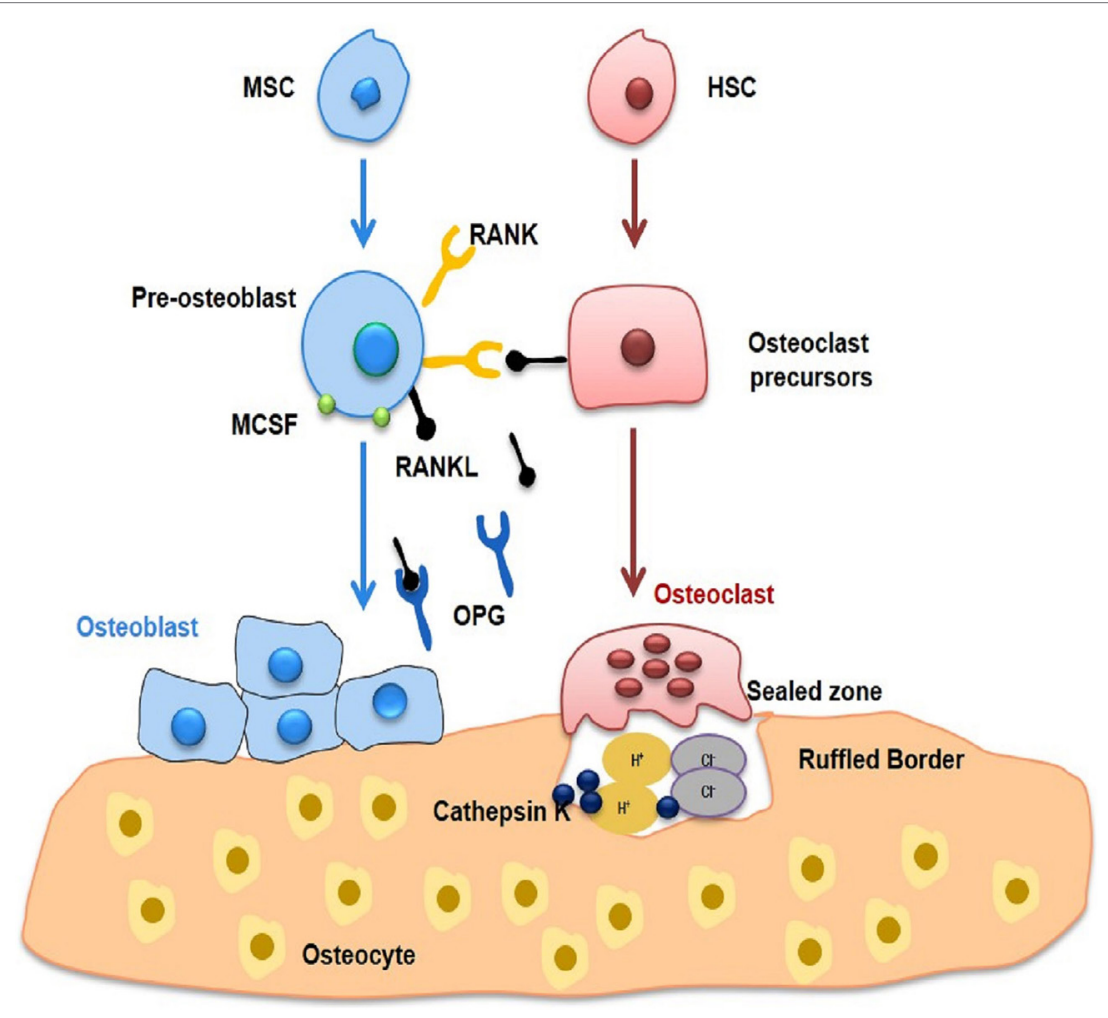

FIGURE 1 | Bone remodelling. Bone undergoes continuous remodelling as a result of interaction between bone-forming osteoblasts and bone-resorbing osteoclasts. Both osteoclasts and osteoblasts lead to fine tuning of osteocytes, which in turn modulates remodelling. Osteoblasts are derivatives of MSCs and produce extracellular bone matrix of type I collagen and non-collagenous proteins, including osteocalcin, osteonectin, and osteopontin. Multinucleated osteoclasts are produced as a result of differentiation of macrophages and monocytes. RANKL in the presence of MCSF is primarily responsible for functioning and activation of osteoclasts leading to bone loss. On the other hand, osteoblasts produce OPG, which inhibits bone loss by inhibiting osteoclastogenesis. MSC, Mesenchymal stem cell; HSC, Hematopoietic stem cell; RANKL, Receptor activator for nuclear factor kappa; OPG, Osteoprotegerin. 
osteoblasts and osteomacs, primarily responsible for removing different remnants of collagen. The different mechanisms responsible for this coupling phenomenon and for propagating this transition of bone formation to bone resorption has always been a subject of controversy, as earlier studies reported that bone functions as a store house for these coupling molecules and release them accordingly during various steps of bone resorption. During reversal phase, osteoblast precursors differentiate and secrete various molecules that are responsible for development of new bone surfaces. In this phase, various factors like IGF (I and II) and TGF- $\beta$ are recruited by MSCs to the bone resorption sites (43). Finally, to attain final shape of newly formed bone, hydroxyapatite gets integrated at these newly developed osteoid (43). The bone remodeling phase comes to termination phase when equilibrium is attained between bone formation and bone resorption via signals initiated by osteocytes. The loss of sclerostin expression at the end of remodeling cycle instigates the osteoclastogenesis. The mature osteoblasts revert back to bone lining phenotype or undergo apoptosis and subsequently get differentiated into osteocytes. To maintain skeletal structural integrity, bones (both cortical and trabecular) need constant remodeling including repairing various micro-cracks developed due to normal wear and tear. Thus, the important aspects of bone remodeling are the repair, development and maintenance of bone along with functioning as a calcium store house of the host.

\section{T LYMPHOCYTES AND OSTEOPOROSIS (IMMUNOPOROSIS)}

Activated T lymphocytes are primary sources of RANKL (44) and TNF- $\alpha$ (45) responsible for bone destruction observed during various pathological (45) and inflammatory conditions $(2,44)$ (Figure 2). Interestingly, $\mathrm{T}$ cells also possess anti-osteoclastogenic properties, as depletion of both $\mathrm{CD} 4^{+} \mathrm{T}$ and $\mathrm{CD} 8^{+} \mathrm{T}$ lymphocytes leads to decreased production of OPG (46-48). Different studies have revealed that $\mathrm{T}$ cell deficient nude mice have normal or elevated bone mineral density (45). These studies suggest that $\mathrm{T}$ cells have an important role in bone remodeling but the exact link between $\mathrm{T}$ cells and osteoclastogenesis particularly in osteoporosis is still not fully elucidated and needs more research thereby giving strong impetus for the emergence of a dedicated novel field to specifically study the role of immune system in osteoporosis, i.e., immunoporosis (with focused emphasis on the role of T lymphocytes).

\section{Th1 Cells and Osteoporosis}

The term Th1 was first given by Tada in 1978 but the clear demonstration of the existence of Th1 cell was provided by Mosmann in $1986(49,50)$. Naive CD4 ${ }^{+} \mathrm{T}$ cells differentiate into Th1 cells when stimulated by interleukin (IL)-12 resulting in the production of IFN- $\gamma$, IL-2, lymphotoxins, TNF- $\alpha$ and granulocytemacrophage colony-stimulating factor $(38,51)$. The production of high levels of IFN- $\gamma$ by Th1 cells induces activation of both phagocytic activity and complement proteins thereby playing an important role in protection against various intracellular pathogens (52). In addition to protection from invading pathogens, Th1 lymphocytes have been associated with development of organ-specific autoimmune diseases (53). Initially, many inflammatory conditions, such as experimental autoimmune encephalomyelitis (EAE), inflammatory bowel disorders (IBD), autoimmune arthritis and collagen-induce arthritis were linked to unchecked Th1 responses $(52,54)$. Interestingly, Th1 cells do not possess such characteristics thereby making it clear that the osteoclastogenic Th cells might belong to a yet unknown subset $(17,54)$. Lately, it has been confirmed that yet another recently defined subset of helper T cells ( $v i z$. Th17 cells) are predominately responsible for causing these inflammation related bone pathologies $(55,56)$. This new subset thus became the fore runner for the modulation and regulation of bone health. Also, majority of cytokines produced from Th1 cells inhibit osteoclastogenesis (57), even small quantities of IFN- $\gamma$ can inhibit osteoclastogenesis through degradation of TRAF6 molecule (9) thereby inhibiting bone loss. Together, these compelling findings establish the osteoprotective role of Th1 responses in the pathogenesis of osteoporosis.

\section{Th2 Cells and Osteoporosis}

Like Th1, the term Th2 was also given by Tada in 1978, and later, Mosmann in $1986(49,50)$ provided a full description about Th2 cells. Th2 cells play an important part in host defense against multi-cellular parasites and in protection against allergies and atopic illnesses. Th 2 cells are produced by stimulating naive $\mathrm{CD} 4^{+}$ $\mathrm{T}$ cells in the presence of IL-4, leading to production of IL-4, IL-5, IL-10 and IL-13 cytokines (12, 34, 51, 57). Th2 cells were initially believed to be responsible for anti-inflammatory activity in various Th1 cell mediated or Th1 model diseases (57). It was also observed that in case of severity of experimental autoimmune myocarditis inhibition of IL- 4 with anti-IL-4 monoclonal antibody reduced the severity of disease (57). The Th2 signature cytokines IL-4, IL-5, and IL-13 have been reported to be associated with inhibition of osteoclastogenesis (58). It has been observed that Th2 cell activation enhances production of $\mathrm{PTH}$, resulting in maintenance of anabolic activity of osteoblasts under various inflammatory conditions (59). Simultaneously, it has also been reported that mice lacking $\mathrm{T}$ lymphocytes are unprotected by catabolic activity of PTH (59). Interestingly, Th2 lymphocytes have also been reported to inhibit bone loss by significantly lowering the RANKL/OPG ratio (59). IL-4 has been observed to inhibit bone resorption under both in vivo and in vitro conditions (60, 61). Low concentrations of Th2 cytokines such as IL-4 and IL-10 have been observed in both the synovial fluid and the peripheral blood of osteoarthritis (OA) patients (62). These findings thus clearly establish the osteoprotective role of Th2 lymphocytes in the pathophysiology of osteoporosis.

\section{Th9 Cells and Osteoporosis}

Th9 cells are recently defined subset of Th cells producing IL-9 and have been associated with immune responses against intestinal worms and immunopathology of various allergic and autoimmune disorders, viz. systemic sclerosis, systemic lupus erythematosus (SLE) and $\operatorname{EAE}(38,63)$. Th9 cells in association with Th2 cells are believed to be promoting inflammation during allergic diseases but it still lacks full validation (64). In other cases, there has been a close association between IL-9 


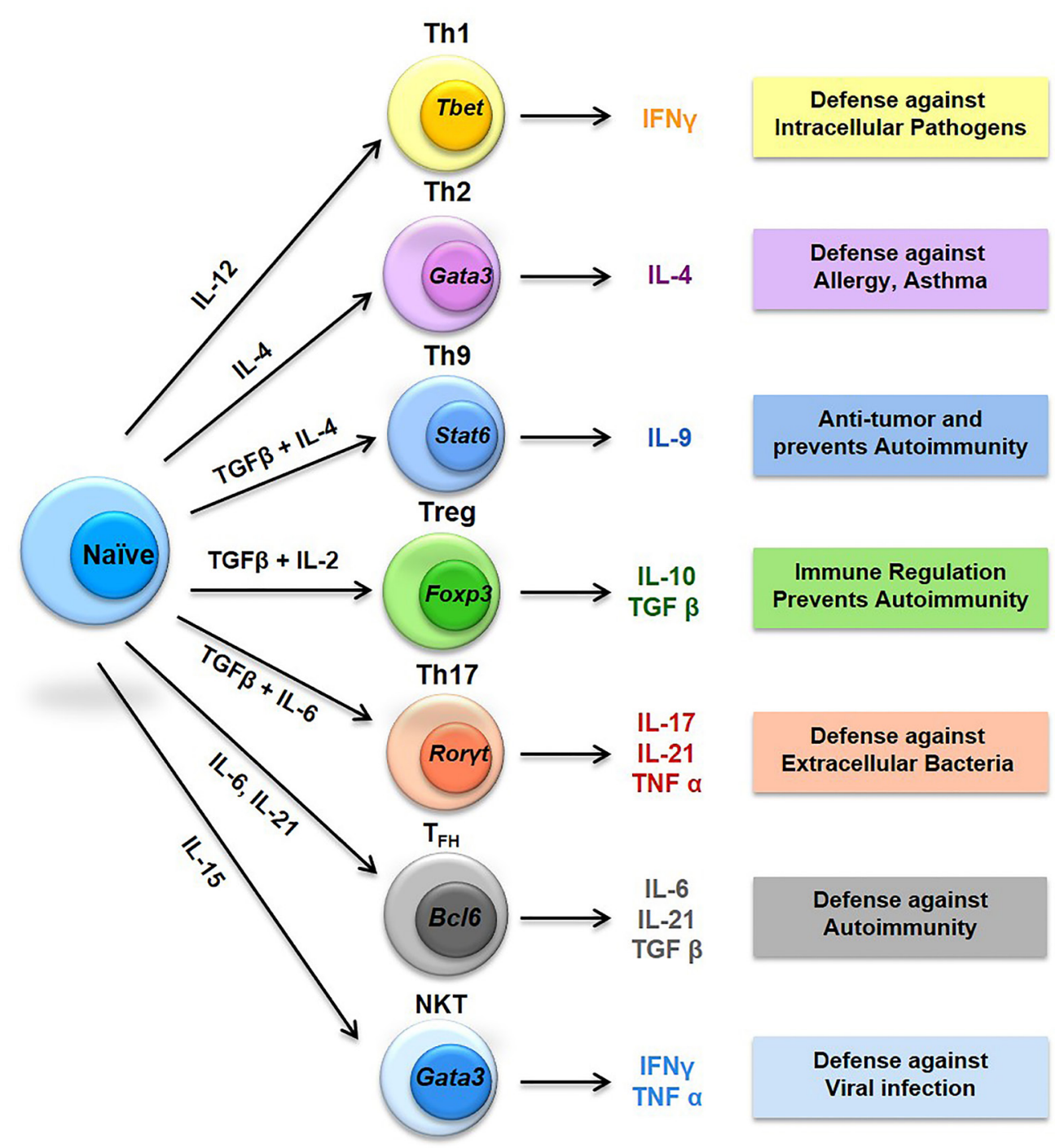

FIGURE 2 | Diversity of T helper (Th) cells. The signature cytokines produced by respective Th cells are shown along with their immunomodulatory properties in boxes. STAT, Signal transducer and activator of transcription; ROR $\gamma$, RAR-related orphan receptor gamma; Foxp3, Forkhead box P3; BCL6, B-cell lymphoma 6.

with Th17 cells development, as IL-9 in the presence of TGF- $\beta$ initiates differentiation of naive $\mathrm{CD}^{+} \mathrm{T}$ cells into Th17 cells (65). In addition, IL-9 has also been reported to amplify the development of Th17 cells during positive autocrine loop (66). In addition, serum levels of IL-9 or total Th9 cell population have been found immensely increased in case of arthritis and OA (38). Together, these studies point towards the role of Th9 cells in various bone conditions like RA but evidences are still lacking for its correlation with osteoporosis, which warrants further research in the field.

\section{Th17 Cells and Osteoporosis}

Th17 cells are associated with protection against bacterial infection and are primarily responsible for induction of various autoimmune diseases via recruitment of signatory cells especially neutrophils $(34,38)$. The differentiation and development of Th17 cells is mainly carried by TGF- $\beta$, IL-6, IL- $1 \beta$ and IL-23. Primary cytokines secreted by Th17 are IL-17A, IL-17F, IL-21 and IL-22 (67). Th17 cells have also been reported to be constitutively present across mucosal surfaces including lamina propria of intestine (68). Th17 cells play an important role in various inflammatory conditions, such as osteoporosis, psoriasis, periodontal disease, RA and IBD $(55,56)$. Th17 cells are thus now often labeled as osteoclastogenic subsets of $\mathrm{T}$ lymphocytes $(17,69)$. Th17 cells enhance osteoclastogenesis by secreting higher levels of IL-1, IL-6, IL-17, RANKL and TNF in addition to low levels of IFN- $\gamma(18,70,71)$. IL-17 enhances osteoclastogenesis by stimulating osteocytes and osteoblasts and potentiates 
osteoclastogenic activity via upregulation of receptor activator of NF- $\mathrm{KB}$ (RANK) production to produce higher levels of RANKL $(57,72)$. IL-17 acts as a pivotal communication point between $\mathrm{T}$ lymphocytes and osteocytes by modulating production of RANKL (73). Although the profile of Th17 lymphocytes in different lymphoid tissues requires further analysis, its role in the pathogenesis of osteoporosis is now well documented, since in osteoporotic patients Th17 cell population has been found to be increased many folds $(34,38)$. In addition, Th17 cells in the blood and peripheral tissues can serve as an important marker for osteoporosis. Altogether, these observations and studies dissect a clear and comprehensive role of Th17 cells in osteoporosis.

\section{Treg Cells and Osteoporosis}

Regulatory $\mathrm{T}$ cells $\left(\mathrm{CD} 4^{+} \mathrm{CD} 25^{+} \mathrm{Foxp}^{+} \mathrm{T}\right.$ cells) represent a special subset of Th cells that are mainly accounted for the prevention of autoimmune diseases, maintaining peripheral tolerance and limiting chronic inflammatory diseases by suppressing and regulating the effector function of Th cells (74). It has been reported that Foxp $3^{+}$Tregs are represented by both natural Treg (nTreg) and adaptive or induced Treg (iTreg) cell populations. nTreg cells develop in the thymus whereas iTreg cells are generated in the periphery $(75,76)$. nTregs represent population of $\mathrm{CD}^{+} \mathrm{T}$ lymphocytes residing in the thymus and constitute approximately $5-10 \%$ of the peripheral naive $\mathrm{CD}^{+} \mathrm{T}$ lymphocyte pool in both mice and humans. They play a significant role in the maintenance of immunological self-tolerance and modulation of immune responses (77). iTregs are found in peripheral lymphoid tissues and are derived from naive T cells (78). IL-10 and TGF- $\beta$ cytokines are mainly recruited for the development and differentiation of iTregs (79). Forkhead transcription factor (Foxp3) usually expressed by Tregs has an important role in the development and functions of Tregs (77). Treg cells presume an important role in immune regulation during various inflammatory and autoimmune diseases, since Tregs regulate secretion and expression of pro-inflammatory and anti-inflammatory cytokines $(18,34,80)$.

Tregs also secrete cytotoxic T-lymphocyte antigen 4, which control immune function upon binding with CD80/CD86 present on mononuclear osteoclast cells thereby leading to inhibition of inflammatory responses (34). Furthermore, inhibition of collagen-induced arthritis in mice was reported to be suppressed by Treg cells (81). Treg cells have been reported to directly inhibit osteoclastogenesis by suppressing RANKL and M-CSF production leading to increased bone volume $(20,82)$. Recently, the CD8 counter part of Treg cells has also been discovered as osteoclast-induced FoxP3 ${ }^{+} \mathrm{CD} 8{ }^{+}$Treg cells which suppress both the formation and activity of osteoclasts via suppression of actin ring formation leading to inhibition of osteoclastogenesis (22). Interestingly, this regulatory bi-directional mechanism does not require the presence of various pro-inflammatory cytokines. Altogether, it has now been well established beyond doubt that any dysregulation in the population or functioning of Tregs would result in enhanced bone loss reported in osteoporosis. Thus, exploring novel pathways and molecular mechanisms regulating the cross talk between Tregs and bone cells is highly desired for future clinical implications.

\section{$\mathrm{T}_{\mathrm{FH}}$ Cells and Osteoporosis}

Follicular helper T lymphocytes are usually found in the follicles of lymphoid tissue and induce production of immunoglobulins from $\mathrm{B}$ cells (83). $\mathrm{T}_{\mathrm{FH}}$ cells express various distinctive genes such as $\mathrm{C}-\mathrm{X}-\mathrm{C}$ chemokine receptor type 5 (CXCR5), inducible T-cell costimulator (ICOS), CD40L, programmed cell death-1 (PD-1), B-cell lymphoma 6 protein and IL-21 (84). Growing evidence has shown that $\mathrm{T}_{\mathrm{FH}}$ cells influence the severity of various autoimmune diseases such as RA and SLE by enhancing generation of reactive autoantibodies from B cells (85). There has been reports of increased number of circulating $\mathrm{T}_{\mathrm{FH}}$ lymphocytes ( $v i z$. CXCR5 $5^{+} \mathrm{PD}-1^{+} \mathrm{CD} 4^{+}$or $\mathrm{CXCR}^{+} \mathrm{ICOS}^{+} \mathrm{CD} 4^{+}$) in SLE patients which correlates with the amount of autoantibodies and SLE severity (86). Specific immunohistochemistry analysis has further confirmed the presence of $\mathrm{T}_{\mathrm{FH}}$ lymphocytes $\left(\mathrm{CD}^{+} \mathrm{CXCR}^{+} \mathrm{ICOS}^{+}\right)$in the synovial tissues of RA patients (38). In addition, in RA patients, there was observed an elevation of CD $19^{+} \mathrm{B}$ cells and increased serum IL-21 which is positively associated with disease scores and presence of anti-citrullinated antibodies $(87,88)$. There has been reports of elevated levels of $\mathrm{T}_{\mathrm{FH}}$ cells in both Sjogren's syndrome patients and RA patients $(88,89)$. These studies provide strong evidence for potentially important roles played by $\mathrm{T}_{\mathrm{FH}}$ cells in the pathogenesis and progression of autoimmune diseases through various pathways. Collectively, these studies establish the role of $\mathrm{T}_{\mathrm{FH}}$ cells in $\mathrm{RA}$ thereby opening new avenues in the field of immunoporosis for further dissecting and delineating the role of $\mathrm{T}_{\mathrm{FH}}$ lymphocytes in pathogenesis of osteoporosis.

\section{Natural Killer T (NKT) Cells and Osteoporosis}

Natural killer T cells represent heterogeneous group of T lymphocytes which share properties of both natural killer cells and T cells. NKT cells are primarily involved in the clearance of transformed and virus-infected cells (90). NKT cells modulate initiation and development of immune responses mediated by both $\mathrm{T}$ and $\mathrm{B}$ cells via production of various growth factors and cytokines (16). NKT cells have been found to regulate development and function of macrophages, monocytes and myeloid dendritic cells $(91,92)$. A recently reported subset of NKT cells called as invariant NKT have been found to regulate the development and differentiation of osteoclasts (93). NKT cells have also been reported in the synovial tissues of RA patients where they constitute up to $20 \%$ of all the lymphocytes (94). The CD56 $6^{\text {bight }}$ subset of NKT cells have been reported with upregulated expression of various chemokine receptors and adhesion molecules responsible for enhanced recruitment of NKT cells (95) thereby engaging and activating monocytes for enhanced osteoclastogenesis in synovium of RA patients (94). T cells and macrophages activated by NKT cell-derived IFN- $\gamma$ also leads to increased secretion of TNF- $\alpha$ (96), a strong pro-osteoclastogenic cytokine. TNF- $\alpha$ enhances osteoclastogenesis in a RANKL-dependent manner either directly or by promoting commitment of progenitors to osteoclast lineage and differentiation or indirectly by stimulating secretion of RANKL and M-CSF by osteoblasts $(97,98)$. In addition, RANKL and MCSF are also produced by NKT cells and 
thus induce osteoclastogenesis which is further upregulated by IL-15 (99). Altogether, these reports elaborate the important role of NKT in the pathogenesis of inflammatory bone diseases. Thus, regulation of NKT cells can be an important aspect for regulating bone loss in osteoporosis.

\section{$\gamma \delta$-T Cells and Osteoporosis}

$\mathrm{T}$ cells present in circulation mainly express $\alpha \beta$-T cell receptor (TCR) chains along with a small subset of $\mathrm{T}$ cells which uniquely expresses TCRs, containing a gamma $(\gamma)$ chain and a delta $(\delta)$ chain named as $\gamma \delta$-T cells. About $1-10 \%$ of $\mathrm{T}$ lymphocytes in periphery of human circulation comprise of $\gamma \delta$-T cells, however, skin and other tissues have more abundant population of $\gamma \delta$-T cells (99). $\gamma \delta$-T cells are more innate-like, unlike their counterpart $\alpha \beta$-T cell which are adaptive. Also, the TCR specificity of $\gamma \delta$-T cells is uniquely directed toward nonpeptide antigens. $\gamma \delta$-T cells are now increasingly being linked with autoimmunity, allergy, hematological tumors (100) and infectious diseases (101). $\gamma \delta$-T cells have recently been reported to produce factors which are important in the healing of various skeletal fractures (102). It has been observed that anti-CD3/ CD28-stimulated $\gamma \delta$ T cells lead to inhibition of human osteoclast formation and simultaneous resorptive activity in vitro. In addition, stimulated $\gamma \delta$-T cells leads to increased production of IFN- $\gamma$ and inhibits expression of IL-17 production (103). $\gamma \delta$-T cells are quite unique and heterogeneous population of

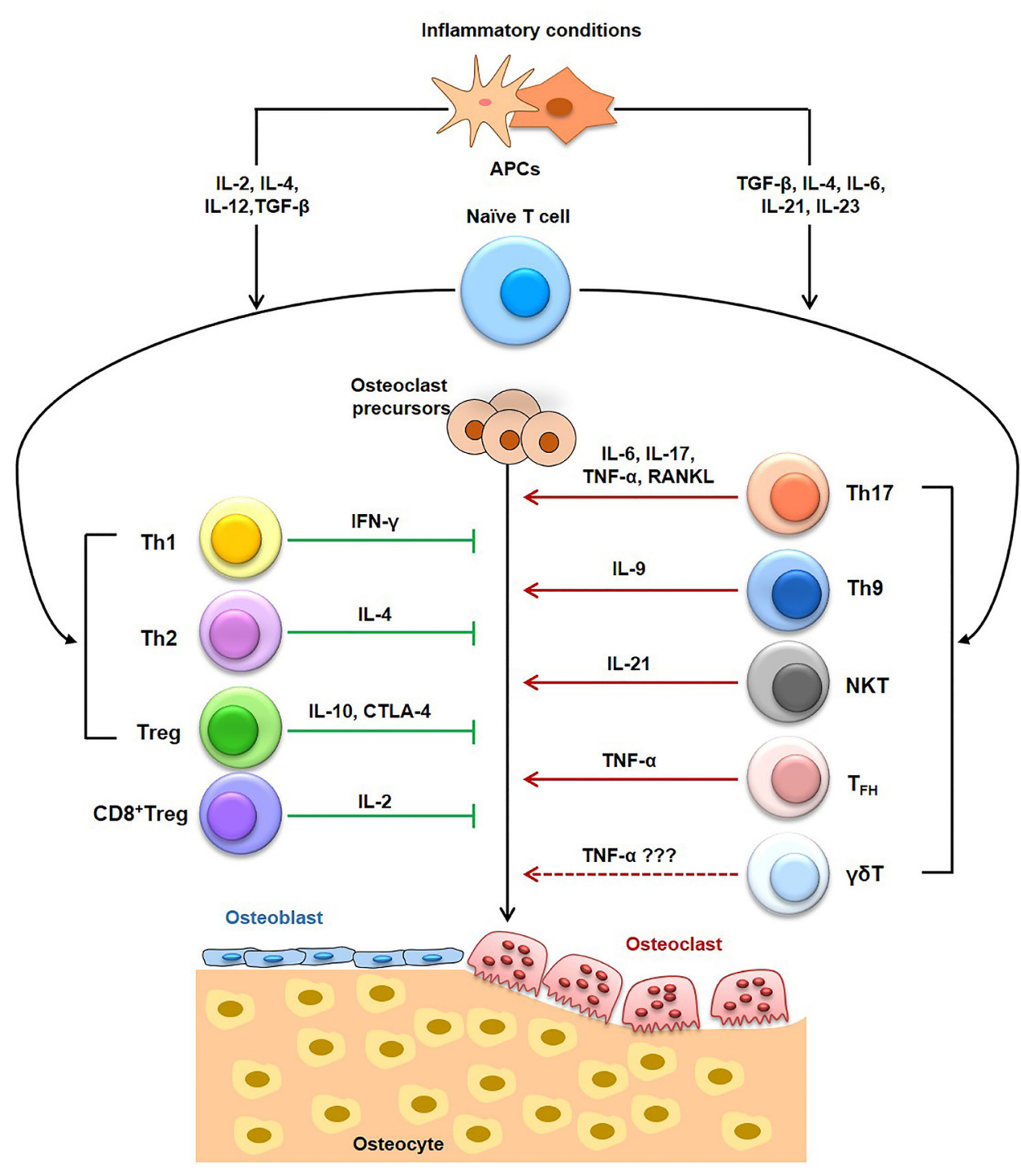

Bone Resorption

FIGURE 3 | Role of T cells in Immunoporosis. T cells, including the T helper (Th) cells, cytotoxic T cells have pivotal role in the induction of osteoporosis-associated bone loss. Within T helper (Th) cells, Th9 cells, Th17 cells, NK T cells, and follicular helper T ( $T_{F H}$ ) cells have been reported to enhance bone loss in osteoporosis. On the other hand, Th1, Th2, Tregs, and CD8T cells have been associated with osteoprotective properties, thereby inhibiting osteoporosis. The role of $\gamma \delta \mathrm{T}$ cells need more studies to relate them with osteoporosis. 
T lymphocytes and are easily lost in patients undergoing aminobisphosphonate treatment for various bone-related pathologies (104). $\gamma \delta$-T cells have been associated with peculiar property of immunomodulation and thus are a promising candidate for treatment of various inflammatory conditions including bone pathologies.

\section{CD8 $^{+} \mathbf{T}$ Cells and Osteoporosis}

$\mathrm{CD}^{+} \mathrm{T}$ cells are yet another established subset of $\mathrm{T}$ lymphocytes which play a key role in cell-mediated responses in the immune system. $\mathrm{CD}^{+} \mathrm{T}$ cells are also referred as cytotoxic T lymphocytes which aid in protection of host from foreign organisms through both lytic and non-lytic means. CD8 ${ }^{+} \mathrm{T}$ cells are responsible for regulating the immune responses and simultaneously eliminating transformed tumor cells $(104,105)$. Another recently defined regulatory subset of $\mathrm{CD} 8^{+} \mathrm{T}$ cells called as Foxp $3^{+} \mathrm{CD} 8^{+}$Tregs has been found to suppress osteoclast formation and activity by secreting various anti-osteoclastogenic cytokines (22). Foxp $3^{+} \mathrm{CD} 8^{+}$ Tregs cells not only regulate the survival of osteoclasts but also affect the maturation of osteoclasts by suppressing their actin ring formation. The recently discovered unique property of osteoclast inducing the generation of FoxP $3{ }^{+} \mathrm{CD} 8^{+}$Treg cells and the ability of FoxP3 ${ }^{+} \mathrm{CD}^{+}$Treg cells to subsequently regulate osteoclast function establishes a bi-directional regulatory loop between these two cells types in the BM (22). CD8 ${ }^{+} \mathrm{T}$ cells have also been reported to play an important role in the pathogenesis of OA (38). These reports thus clearly establish the important role of $\mathrm{CD}^{+} \mathrm{T}$ cells in bone health, but still evidences for their role in osteoporosis is not well established and needs further research.

\section{CONCLUSION AND FUTURE PERSPECTIVES}

Inflammatory bone conditions including RA, OA and osteoporosis arise due to dysregulation of the homeostatic nexus between bone and immune system thereby leading to enhanced bone loss. Various strategies are now being developed for inhibiting inflammation induced bone loss. One direct approach of inhibiting osteoclastogenesis could be interfering with inflammatory pathways thereby providing an alternate method for managing inflammatory bone loss/damage. The emergence of "immunoporosis" as an independent field of research would thus give a novel and unique insight into the underlying immune-skeletal interaction between both immune cells ( $\mathrm{T}$ cells) and bone cells (Figure 3). Since the role of immune system, in general, has been implicated for elucidating the pathogenesis of numerous inflammatory diseases, however, the immunoporosis aspect, i.e., the role of specific subsets of $\mathrm{T}$ lymphocytes in osteoporosis is still unclear. Thus, it will be important to see the course of various subsets of T cells in the development and progression of osteoporosis. Both $\mathrm{CD}^{+}$(Th1, Th2, Th9, Th17, Treg, NKT, $\gamma \delta$ T cell subsets) and $\mathrm{CD}^{+} \mathrm{T}$ cells play an important role in regulating bone health. Th17 cells are one of the major inducers of bone loss via expression of higher levels of RANKL and TNF- $\alpha$ (17, $106,107)$. On the other hand, Tregs are major inhibitors of bone loss $(108,109)$ through production of IL- 4 , IL- 10 and TGF- $\beta 1$ cytokines $(108,109)$. Tregs also inhibit the effector functioning of Th17 cells in inflammation-induced bone loss $(109,110)$. Tregs also lead to suppression of bone loss by inhibiting differentiation

TABLE 1 | Role of various T cell cytokines in osteoclastogenesis.

\begin{tabular}{|c|c|c|c|c|}
\hline Cytokine & Source & Modulation of immunity & Osteoclastogenic function & Reference \\
\hline Interleukin (IL)-4 & Th2 & Humoral immunity & Inhibits osteoclastogenesis & $(115)$ \\
\hline IL-6 & $\begin{array}{l}\text { Macrophage, } \\
\text { dendritic cells (DCs) }\end{array}$ & $\begin{array}{l}\text { Pro-inflammation, } \\
\text { Th17 induction }\end{array}$ & Activation of osteoclastogenesis & $(116)$ \\
\hline IL-10 & Regulatory T (Treg) & Anti-inflammatory & Suppress bone resorption & $(117)$ \\
\hline IL-15 & NK cells & Pro-inflammatory cytokine & $\begin{array}{l}\text { Enhances RANK ligand (RANKL) and macrophage } \\
\text { colony-stimulating factor expression }\end{array}$ & (99) \\
\hline $\mathrm{IL}-17$ & T cells & Pro-inflammatory cytokine & RANKL expression and vigorous pro-inflammatory potency & $(118)$ \\
\hline IL-18 & Macrophage & $\begin{array}{l}\text { Th1 differentiation, } \\
\text { interferon (IFN)- } \gamma \text { Induction }\end{array}$ & Inhibits TNF- $\alpha$ mediated osteoclast & $(119)$ \\
\hline IL-23 & Macrophage and DCs & Th17 induction & Indirect osteoclast activation & $(17)$ \\
\hline IL-27 & Macrophage and DCs & $\begin{array}{l}\text { Th1and Treg } \\
\text { Th17 induction }\end{array}$ & $\begin{array}{l}\text { Inhibits osteoclast formation, blocking receptor } \\
\text { activator of NF-kB (RANK)-dependent osteoclastogenesis }\end{array}$ & $(120)$ \\
\hline MCSF & Th1 & Pro-inflammatory & Inhibits osteoclastogenesis & $(121)$ \\
\hline $\mathrm{IFN}-\gamma$ & Th1, NK cells & Cellular immunity & Inhibits osteoclastogenesis & $(116)$ \\
\hline Osteoprotegerin & Osteoclasts & Decoy receptor for RANKL & Inhibits osteoclastogenesis & $(122)$ \\
\hline RANKL & Th17 cells & $\begin{array}{l}\text { Osteoclast differentiation } \\
\text { DCs maturation }\end{array}$ & Osteoclast activation via RANK & $(123)$ \\
\hline RANK & Osteoclasts, DCs & DCs activation & Osteoclast differentiation and activation & $(121)$ \\
\hline TNF- $\alpha$ & Th17, macrophage DCs & Pro-inflammatory cytokine & Indirect osteoclastic activation through RANKL & $(123)$ \\
\hline $\begin{array}{l}\text { Transforming growth } \\
\text { factor beta }\end{array}$ & Multiple cell lines & $\begin{array}{l}\text { Blocks activation of lymphocytes } \\
\text { and monocytes derived phagocytosis }\end{array}$ & $\begin{array}{l}\text { Indirect osteoclast activation, Inhibits osteoblast } \\
\text { differentiation }\end{array}$ & $(124)$ \\
\hline
\end{tabular}


of monocytes into osteoclasts under both in vitro and in vivo conditions $(20,75,111)$ (Table 1).

Since osteoporosis affects more than $50 \%$ of female population and one-fourth of males above age $50(3,20)$, osteoporotic patients are very higher in number than OA and RA (3). The current therapies employed for the treatment of osteoporosis, viz. bisphosphonates, strontium ranelate, selective estrogen receptor modulators, PTH (teriparatide), etc. provide remission of inflammation with little relief to the patients (112). Therefore, the need for new and effective future therapeutics are need of the hour for long-term relief from various bone loss mediated pathologies. This could be made possible only upon having a clear and better understanding of immune-skeletal biology which can be clearly defined and delineated under the novel field of immunoporosis. Thus, advanced exploration and research under the aegis of immunoporosis would lead to novel opportunities and avenues for development of enhanced therapies. Recently, the inclusion of probiotics ( $v i a$ modulation of host immune system) as a supplementary therapy for bone loss represents one such class $(20,113,114)$. Thus, a better understanding of the nexus between both the systems should be at heart of future research in the area. The establishment of

\section{REFERENCES}

1. Eisman JA, Bogoch ER, Dell R, Harrington JT, McKinney RE Jr, McLellan A, et al. Making the first fracture the last fracture: ASBMR task force report on secondary fracture prevention. JBone Miner Res (2012) 27:2039-46. doi:10.1002/jbmr.1698

2. Kawai M, Mödder UI, Khosla S, Rosen CJ. Emerging therapeutic opportunities for skeletal restoration. Nat Rev Drug Discov (2011) 10:141-56. doi:10.1038/nrd3299

3. IOF Compendium of Osteoporosis. 1st ed (2017). Available from: www. iofbonehealth.org

4. Kates SL, Kates OS, Mendelson DA. Advances in the medical management of osteoporosis. Injury (2007) 38:S17-23. doi:10.1016/j.injury.2007.08.007

5. Johnell O, Kanis JA. An estimate of the worldwide prevalence and disability associated with osteoporotic fractures. Osteoporos Int (2006) 17:1726-33. doi:10.1007/s00198-006-0172-4

6. Yu B, Wang CY. Osteoporosis: the result of an 'aged' bone microenvironment. Trends Mol Med (2016) 22(8):641-4. doi:10.1016/j.molmed.2016. 06.002

7. Geusens P, Lems WF. Osteoimmunology and osteoporosis. Arthritis Res Ther (2011) 13(5):242. doi:10.1186/ar3375

8. Nakashima T, Takayanagi H. Osteoimmunology: crosstalk between the immune and bone systems. J Clin Immunol (2009) 29:555-67. doi:10.1007/ s10875-009-9316-6

9. McInnes IB, Schett G. Cytokines in the pathogenesis of rheumatoid arthritis. Nat Rev Immunol (2007) 7:429-42. doi:10.1038/nri2094

10. Takayanagi H. Osteoimmunology and the effects of the immune system on bone. Nat Rev Rheumatol (2009) 5:667-76. doi:10.1038/nrrheum.2009.217

11. Zhao E, Xu H, Wang L, Kryczek I, Wu K, Hu Y, et al. Bone marrow and the control of immunity. Cell Mol Immunol (2012) 9:11-9. doi:10.1038/ cmi.2011.47

12. Zhu J, Yamane H, Paul WE. Differentiation of effector CD4 T cell populations. Annu Rev Immunol (2010) 28:445-89. doi:10.1146/annurev-immunol030409-101212

13. Murphy KM, Reiner SL. The lineage decisions of helper T cells. Nat Rev Immunol (2002) 2:933-44. doi:10.1038/nri954

14. Hori S, Nomura T, Sakaguchi S. Control of regulatory T cell development by the transcription factor Foxp3. Science (2003) 299:1057-61. doi:10.1126/ science. 1079490

15. Harrington LE, Hatton RD, Mangan PR, Turner H, Murphy TL, Murphy KM, et al. Interleukin 17-producing CD4+ effector T cells develop via a lineage "immunoporosis" as an independent field of modern biology catering to the recent developments in the field will thus provide new paradigms for development of focused novel therapeutic strategies for managing osteoporosis.

\section{AUTHOR CONTRIBUTIONS}

RS suggested the focus and outline of the review along with writing the review. HD participated in the writing of the review along with creating figure illustrations. PM provided valuable inputs for manuscript preparation.

\section{ACKNOWLEDGMENTS}

This work was financially supported by a project from UGCFRPS (30-12/2014), Govt. of India, sanctioned to RS. RS and HD acknowledges Department of Zoology, Dr. Harisingh Gour Central University, Sagar (MP), India for providing infrastructural facilities. RS also thanks Department of Biotechnology, All India Institute of Medical Sciences (AIIMS), New Delhi, India for providing necessary facilities. HD thanks UGC for research fellowship.

distinct from the T helper type 1 and 2 lineages. Nat Immunol (2005) 6 : 1123-32. doi:10.1038/ni1254

16. Martin-Fontecha LL, Thomsen S, Brett C, Gerard M, Lipp A, Lanzavecchia F, et al. Induced recruitment of NK cells to lymph nodes provides IFN-gamma for T(H)1 priming. Nat Immunol (2004) 5:1260-5. doi:10.1038/ni1138

17. Sato K, Suematsu A, Okamoto K, Yamaguchi A, Morishita Y, Kadono Y, et al. Th17 functions as an osteoclastogenic helper T cell subset that links $\mathrm{T}$ cell activation and bone destruction. J Exp Med (2006) 203:2673-82. doi:10.1084/jem.20061775

18. Dar HY, Singh A, Shukla P, Rajaneesh A, Mondal RK, Mishra PK, et al. High dietary salt intake correlates with modulated Th17-Treg cell balance resulting in enhanced bone loss and impaired bone microarchitecture in male mice. Sci Rep (2018) 8:2503. doi:10.1038/s41598-018-20896-y

19. Zaiss MM, Axmann R, Zwerina J, Polzer K, Gückel E, Skapenko A, et al. Treg cells suppress osteoclast formation: a new link between the immune system and bone. Arthritis Rheum (2007) 56:4104-12. doi:10.1002/art. 23138

20. Dar HY, Shukla P, Mishra PK, Anupam R, Mondal RK, Tomar GB, et al. Lactobacillus acidophilus inhibits bone loss and increases bone heterogeneity in osteoporotic mice via modulating Treg-Th17 cell balance. Bone Rep (2018) 8:46-56. doi:10.1016/j.bonr.2018.02.001

21. Kelchtermans H, Geboes L, Mitera T, Huskens D, Leclercq G, Matthys P. Activated $\mathrm{CD}^{+} \mathrm{CD} 25^{+}$regulatory $\mathrm{T}$ cells inhibit osteoclastogenesis and collagen-induced arthritis. Ann Rheum Dis (2009) 68:744-50. doi:10.1136/ ard.2007.086066

22. Shashkova EV, Trivedi J, Cline-Smith AB, Ferris C, Buchwald ZS, Gibb J, et al. Osteoclast primed Foxp3 ${ }^{+}$CD8 T cells induce T-bet, Eomesodermin and IFN- $\gamma$ to regulate bone resorption. J Immunol (2016) 197(3):726-35. doi:10.4049/jimmunol.1600253

23. Schett G, David J-P. The multiple faces of autoimmune-mediated bone loss. Nat Rev Endocrinol (2010) 6:698-706. doi:10.1038/nrendo.2010.190

24. Takada I, Kouzmenko AP, Kato S. Wnt and PPARgamma signaling in osteoblastogenesis and adipogenesis. Nat Rev Rheumatol (2009) 5:442-7. doi:10.1038/nrrheum.2009.137

25. Walsh MC, Kim N, Kadono Y, Rho J, Lee SY, Lorenzo J, et al. Osteoimmunology: interplay between the immune system and bone metabolism. Annu Rev Immunol (2006) 24:33-63. doi:10.1146/annurev.immunol.24. 021605.090646

26. Chang MK, Raggatt LJ, Alexander KA, Kuliwaba JS, Fazzalari NL, Schroder K, et al. Osteal tissue macrophages are intercalated throughout human and mouse bone lining tissues and regulate osteoblast function in vitro 
and in vivo. J Immunol (2008) 181:1232-44. doi:10.4049/jimmunol.181. 2.1232

27. Hume DA. The mononuclear phagocyte system. Curr Opin Immunol (2006) 18:49-53. doi:10.1016/j.coi.2005.11.008

28. Cho SW, Soki FN, Koh AJ, Eber MR, Entezami P, Park SI, et al. Osteal macrophages support physiologic skeletal remodeling and anabolic actions of parathyroid hormone in bone. Proc Natl Acad Sci U S A (2014) 111:1545-50. doi:10.1073/pnas.1315153111

29. Nicolaidou V, Wong MM, Redpath AN, Ersek A, Baban DF, Williams LM, et al. Monocytes induce STAT3 activation in human mesenchymal stem cells to promote osteoblast formation. PLoS One (2012) 7:e39871. doi:10.1371/ journal.pone.0039871

30. Vi L, Baht GS, Whetstone H, Ng A, Wei Q, Poon R, et al. Macrophages promote osteoblastic differentiation in-vivo: implications in fracture repair and bone homeostasis. J Bone Miner Res (2014) 30:1090-102. doi:10.1002/ jbmr.2422

31. Wolff J. Das Gesetz der Transformation des Knochens. Berlin: August Hirschwald (1892).

32. Sommerfeldt D, Rubin C. Biology of bone and how it orchestrates the form and function of the skeleton. Eur Spine J (2001) 10:S86-95. doi:10.1007/ s005860100283

33. Rodan GA, Martin TJ. Role of osteoblasts in hormonal control of bone resorption - a hypothesis. Calc Tissue Int (1981) 33:349-51. doi:10.1007/ BF02409454

34. Dar HY, Azam Z, Anupam R, Mondal RK, Srivastava RK. Osteoimmunology: the Nexus between bone and immune system. Front Biosci (2018) 23:464-92. doi: 10.2741/4600

35. Kanis JA. Calcium metabolism. Prog Basic Clin Pharmacol (1990) 4:1-27.

36. Heino TJ, Hentunen TA, Vnnen HK. Osteocytes inhibit osteoclastic bone resorption through transforming growth factor- $\beta$ : enhancement by estrogen. J Cell Biochem (2002) 85:185-97. doi:10.1002/jcb.10109

37. Swarthout JT, D’Alonzo RC, Selvamurugan N, Partridge NC. Parathyroid hormone-dependent signaling pathways regulating genes in bone cells. Gene (2002) 282:1-17. doi:10.1016/S0378-1119(01)00798-3

38. Li X, Qin L, Bergenstock M, Bevelock LM, Novack DV, Partridge NC. Parathyroid hormone stimulates osteoblastic expression of MCP-1 to recruit and increase the fusion of pre/osteoclasts. JBiol Chem (2007) 282:33098-106. doi:10.1074/jbc.M611781200

39. McHugh KP, Hodivala-Dilke K, Zheng MH, Namba N, Jonathan L, Novack D, et al. Mice lacking $\beta 3$ integrins are osteosclerotic because of dysfunctional osteoclasts. J Clin Invest (2000) 105:433-40. doi:10.1172/JCI8905

40. Teitelbaum SL. Bone resorption by osteoclasts. Science (2000) 289:1504-8. doi:10.1126/science.289.5484.1504

41. Saftig P, Hunziker E, Wehmeyer O, Jones S, Boyde A, Rommerskirch W, et al. Impaired osteoclastic bone resorption leads to osteopetrosis in cathepsin-K-deficient mice. Proc Natl Acad Sci U S A (1998) 95:13453-8. doi:10.1073/ pnas. 95.23 .13453

42. Takahashi F, Takahashi K, Shimizu K, Cui R, Tada N, Takahashi H, et al. Osteopontin is strongly expressed by alveolar macrophages in the lungs of acute respiratory distress syndrome. Lung (2004) 182:173-85. doi:10.1007/ s00408-004-0309-1

43. Tang Y, Wu X, Lei W, Pang L, Wan C, Shi Z, et al. TGF-betal-induced migration of bone mesenchymal stem cells couples bone resorption with formation. Nat Med (2009) 15:757-65. doi:10.1038/nm.1979

44. Kong YY, Feige U, Sarosi I, Bolon B, Tafuri A, Morony S, et al. Activated $\mathrm{T}$ cells regulate bone loss and joint destruction in adjuvant arthritis through osteoprotegerin ligand. Nature (1999) 402:304-9. doi:10.1038/46303

45. Cenci S, Weitzmann MN, Roggia C, Namba N, Novack D, Woodring J, et al. Estrogen deficiency induces bone loss by enhancing T-cell production of TNF-alpha. J Clin Invest (2001) 06:1229-37. doi:10.1172/JCI11066

46. Grcevic D, Lee SK, Marusic A, Lorenzo JA. Depletion of CD4 and CD8 T lymphocytes in mice in vivo enhances 1,25-dihydroxyvitamin D3-stimulated osteoclast-like cell formation in vitro by a mechanism that is dependent on prostaglandin synthesis. JImmunol (2000) 165:4231-8. doi:10.4049/ jimmunol.165.8.4231

47. Choi Y, Woo KM, Ko SH, Lee YJ, Park SJ, Kim HM, et al. Osteoclastogenesis is enhanced by activated B cells but suppressed by activated CD8+ T cells. Eur J Immunol (2001) 31:2179-88. doi:10.1002/1521-4141(200107) 31:7<2179::AID-IMMU2179>3.0.CO;2-X
48. Toraldo G, Roggia C, Qian WP, Pacifici R, Weitzmann MN. IL-7 induces bone loss in vivo by induction of receptor activator of nuclear factor kappa $\mathrm{B}$ ligand and tumor necrosis factor alpha from T cells. Proc Natl Acad Sci US A (2003) 100:125-30. doi:10.1073/pnas.0136772100

49. Tada T, Takemori T, Okumura K, Nonaka M, Tokuhisa T. Two distinct types of helper $\mathrm{T}$ cells involved in the secondary antibody response: independent and synergistic effects of Ia- and Ia+ helper T cells. J Exp Med (1978) 147:446-58. doi:10.1084/jem.147.2.446

50. Mosmann TR, Cherwinski H, Bond MW, Giedlin MA, Coffman RL. Two types of murine helper T cell clone. I. Definition according to profiles of lymphokine activities and secreted proteins. J Immunol (1986) 136: 2348-57.

51. Ren W, Liu G, Chen S, Yin J, Wang J, Tan B, et al. Melatonin signaling in T cells: functions and applications. J Pineal Res (2017) 62(3):e12394. doi:10.1111/jpi.12394

52. Cosmi L, Maggi L, Santarlasci V, Liotta F, Annunziato F. T helper cells plasticity in inflammation. Cytometry A (2014) 85A:36-42. doi:10.1002/ cyto.a. 22348

53. Hirahara K, Poholek A, Vahedi G, Laurence A, Kanno Y, Milner JD, et al. Mechanisms underlying helper T-cell plasticity: implications for immunemediated disease. J Allergy Clin Immunol (2013) 131:1276-87. doi:10.1016/j. jaci.2013.03.015

54. Takayanagi H, Ogasawara K, Hida S, Chiba T, Murata S, Sato K, et al. T-cell-mediated regulation of osteoclastogenesis by signalling cross-talk between RANKL and IFN- $\gamma$. Nature (2000) 408:600-5. doi:10.1038/35046102

55. Miossec P, Korn T, Kuchroo VK. Interleukin-17 and type 17 helper T cells. $N$ Engl J Med (2009) 361:888-98. doi:10.1056/NEJMra0707449

56. Martinez GJ, Nurieva RI, Yang XO, Dong C. Regulation and function of pro-inflammatory TH17 cells. Ann N Y Acad Sci (2008) 1143:188-211. doi:10.1196/annals.1443.021

57. Raphael I, Nalawade S, Eagar TN, Forsthuber TG. T cell subsets and their signature cytokines in autoimmune and inflammatory diseases. Cytokine (2015) 74:5-17. doi:10.1016/j.cyto.2014.09.011

58. Palmqvist P, Lundberg P, Persson E, Johansson A, Lundgren I, Lie A, et al. Inhibition of hormone and cytokine-stimulated osteoclastogenesis and bone resorption by interleukin- 4 and interleukin-13 is associated with increased osteoprotegerin and decreased RANKL and RANK in a STAT6dependent pathway. J Biol Chem (2006) 281:2414-29. doi:10.1074/jbc. M510160200

59. Pacifici R. T cells: critical bone regulators in health and disease. Bone (2010) 47:461-71. doi:10.1016/j.bone.2010.04.611

60. Miossec P, Chomarat P, Dechanet J, Moreau JF, Roux JP, Delmas P, et al. Interleukin-4 inhibits bone resorption through an effect on osteoclasts and proinflammatory cytokines in an ex vivo model of bone resorption in rheumatoid arthritis. Arthritis Rheum (1994) 37:1715-22. doi:10.1002/ art.1780371202

61. Riancho JA, Zarrabeitia MT, Gonzalez-Macias J. Interleukin-4 modulates osteoclast differentiation and inhibits the formation of resorption pits in mouse osteoclast cultures. Biochem Biophys Res Commun (1993) 196:678-85. doi:10.1006/bbrc. 1993.2303

62. Partsch G, Wagner E, Leeb BF, Broll H, Dunky A, Smolen JS. T cell derived cytokines in psoriatic arthritis synovial fluids. Ann Rheum Dis (1998) 57:691-3. doi:10.1136/ard.57.11.691

63. Schmitt E, Klein M, Bopp T. Th9 cells, new players in adaptive immunity. Trends Immunol (2014) 35(2):61-8. doi:10.1016/j.it.2013.10.004

64. Jabeen R, Kaplan MH. The symphony of the ninth: the development and function of Th9 cells. Curr Opin Immunol (2012) 24:303-7. doi:10.1016/j. coi.2012.02.001

65. Locksley RM. Nine lives: plasticity among T helper cell subsets. J Exp Med (2009) 206:1643-6. doi:10.1084/jem.20091442

66. Nowak EC, Weaver CT, Turner H, Begum-Haque S, Becher B, Schreiner B, et al. IL-9 as a mediator of Th17-driven inflammatory disease. J Exp Med (2009) 206:1653-60. doi:10.1084/jem.20090246

67. McGeachy MJ, Cua DJ. Th17 cell differentiation: the long and winding road. Immunity (2008) 28:445-53. doi:10.1016/j.immuni.2008.03.001

68. Ivanov II, McKenzie BS, Zhou L, Tadokoro CE, Lepelley A, Lafaille JJ, et al. The orphan nuclear receptor ROR gamma $\mathrm{T}$ directs the differentiation program of proinflammatory IL-17+ T helper cells. Cell (2006) 126:1121-33. doi:10.1016/j.cell.2006.07.035 
69. Ciucci T, Ibáñez L, Boucoiran A, Birgy-Barelli E, Pène J, Abou-Ezzi G, et al. Bone marrow Th17 TNF $\alpha$ cells induce osteoclast differentiation, and link bone destruction to IBD. Gut (2015) 64:1072-81. doi:10.1136/gutjnl-2014-306947

70. Komatsu N, Takayanagi H. Autoimmune arthritis: the interface between the immune system and joints. Adv Immunol (2012) 115:45-71. doi:10.1016/ B978-0-12-394299-9.00002-3

71. Waisman A. Thelper cell populations: as flexible as the skin? Eur J Immunol (2011) 41:2539-43. doi:10.1002/eji.201141938

72. Adamopoulos IE, Chao CC, Geissler R, Laface D, Blumenschein W, Iwakura Y, et al. Interleukin-17A upregulates receptor activator of NF-kappaB on osteoclast precursors. Arthritis Res Ther (2010) 12:R29. doi:10.1186/ar2936

73. Xiong J, Piemontese M, Thostenson JD, Weinstein RS, Manolagas SC, O’Brien CA. Osteocyte-derived RANKL is a critical mediator of the increased bone resorption caused by dietary calcium deficiency. Bone (2014) 66C:146-54. doi:10.1016/j.bone.2014.06.006

74. de Rezende L, Silva IV, Rangel LB, Guimarães MC. Regulatory T cell as a target for cancer therapy. Arch Immunol Ther Exp (2010) 58:179-90. doi:10.1007/s00005-010-0075-0

75. Yuan FL, Li X, Lu WG, Xu RS, Zhao YQ, Li CW, et al. Regulatory T cells as a potent target for controlling bone loss. Biochem Biophys Res Commun (2010) 402:173-6. doi:10.1016/j.bbrc.2010.09.120

76. Lan Q, Fan H, Quesniaux V, Ryffel B, Liu Z, Zheng SG. Induced Foxp3(+) regulatory T cells: a potential new weapon to treat autoimmune and inflammatory diseases? J Mol Cell Biol (2012) 4:22-8. doi:10.1093/jmcb/mjr039

77. Wang M, Tian T, Yu S, He N, Ma D. Th17 and Treg cells in bone related diseases. Clin Dev Immunol (2013) 2013:203705. doi:10.1155/2013/203705

78. Apostolou I, von Boehmer H. In vivo instruction of suppressor commitment in naive T cells. J Exp Med (2004) 199:1401-8. doi:10.1084/jem. 20040249

79. Curotto de Lafaille MA, Lafaille JJ. Natural and adaptive Foxp3+ regulatory T cells: more of the same or a division of labor? Immunity (2009) 30:626-35. doi:10.1016/j.immuni.2009.05.002

80. Miyara M, Sakaguchi S. Natural regulatory T cells: mechanisms of suppression. Trends Mol Med (2007) 13:108-16. doi:10.1016/j.molmed.2007. 01.003

81. Srivastava RK, Tomar GB, Barhanpurkar AP, Gupta N, Pote ST, Mishra GC. IL-3 attenuates collagen-induced arthritis by modulating the development of Foxp3+ regulatory T cells. J Immunol (2011) 186:2262-72. doi:10.4049/ jimmunol.1002691

82. Okamoto K, Nakashima T, Shinohara M, Negishi-Koga T, Komatsu N, Terashima A, et al. Osteoimmunology: the conceptual framework unifying the immune and skeletal systems. Physiol Rev (2017) 97:1295-349. doi:10.1152/physrev.00036.2016

83. Ueno H, Banchereau J, Vinuesa CG. Pathophysiology of T follicular helper cells in humans and mice. Nat Immunol (2015) 16(2):142-52. doi:10.1038/ ni.3054

84. Crotty S. Follicular helper CD4 T cells (TFH). Annu Rev Immunol (2011) 29:621-63. doi:10.1146/annurev-immunol-031210-101400

85. Ma CS, Deenick EK. Human T follicular helper (Tfh) cells and disease. Immunol Cell Biol (2014) 92:64-71. doi:10.1038/icb.2013.55

86. Simpson N, Gatenby PA, Wilson A, Malik S, Fulcher DA, Tangye SG, et al. Expansion of circulating $\mathrm{T}$ cells resembling follicular helper $\mathrm{T}$ cells is a fixed phenotype that identifies a subset of severe systemic lupus erythematosus. Arthritis Rheum (2010) 62(1):234-44. doi:10.1002/art.25032

87. Ma J, Zhu C, Ma B, Tian J, Baidoo SE, Mao C, et al. Increased frequency of circulating follicular helper $\mathrm{T}$ cells in patients with rheumatoid arthritis. Clin Dev Immunol (2012) 2012:827480. doi:10.1155/2012/827480

88. Wang J, Shan Y, Jiang Z, Feng J, Li C, Ma L, et al. High frequencies of activated $\mathrm{B}$ cells and $\mathrm{T}$ follicular helper cells are correlated with disease activity in patients with new-onset rheumatoid arthritis. Clin Exp Immunol (2013) 174:212-20. doi:10.1111/cei.12162

89. Li XY, Wu ZB, Ding J, Zheng ZH, Li XY, Chen LN, et al. Role of the frequency of blood CD4(+) CXCR5(+) CCR6(+) T cells in autoimmunity in patients with Sjogren's syndrome. Biochem Biophys Res Commun (2012) 422:238-44. doi:10.1016/j.bbrc.2012.04.133

90. Lanier LL. Nk cell recognition. Annu Rev Immunol (2004) 23:225-74. doi:10.1146/annurev.immunol.23.021704.115526

91. Fujii S, Shimizu K, Smith C, Bonifaz L, Steinman RM. Activation of natural killer $\mathrm{T}$ cells by alpha-galactosylceramide rapidly induces the full maturation of dendritic cells in vivo and thereby acts as an adjuvant for combined CD4 and CD8 T cell immunity to a co-administered protein. J Exp Med (2003) 198:267-79. doi:10.1084/jem.20030324

92. Hermans IF, Silk JD, Gileadi U, Salio M, Mathew B, Ritter G, et al. NKT cells enhance $\mathrm{CD} 4+$ and $\mathrm{CD} 8+\mathrm{T}$ cell responses to soluble antigen in vivo through direct interaction with dendritic cells. J Immunol (2003) 171:5140-7. doi:10.4049/jimmunol

93. Hu M, Bassett JHD, Danks L, Howell PGT, Xu K, Spanoudakis E, et al. Activated invariant NKT cells regulate osteoclast development and function. J Immunol (2011) 186:2910-7. doi:10.4049/jimmunol.1002353

94. De Matos CT, Berg L, Michaëlsson J, Felländer-Tsai L, Kärre K, Söderström K. Activating and inhibitory receptors on synovial fluid natural killer cells of arthritis patients: role of CD94/NKG2A in control of cytokine secretion. Immunology (2007) 122:291-301. doi:10.1111/j.1365-2567.2007.02638.x

95. Soler UD, Butcher EC. Unique subpopulations of CD56+ NK and NK-peripheral blood lymphocytes identified by chemokine receptor expression repertoire. J Immunol (2001) 166:6477-82. doi:10.4049/jimmunol.166. 11.6477

96. Biburger M, Tiegs G. Alpha-galactosylceramide-induced liver injury in mice is mediated by TNF-alpha but independent of Kupffer cells. J Immunol (2005) 175:1540-50. doi:10.4049/jimmunol.175.3.1540

97. Lam J, Takeshita S, Barker JE, Kanagawa O, Ross FP, Teitelbaum SL. TNFalpha induces osteoclastogenesis by direct stimulation of macrophages exposed to permissive levels of RANK ligand. J Clin Invest (2000) 106:1481-8. doi:10.1172/JCI11176

98. Teitelbaum SL. Osteoclasts; culprits in inflammatory osteolysis. Arthritis Res Ther (2006) 8:201. doi:10.1186/ar1857

99. Hayday C. $\gamma \delta$ T cells and the lymphoid stress-surveillance response. Immunity (2009) 31:184-96. doi:10.1016/j.immuni.2009.08.006

100. Strid J, Roberts SJ, Filler RB, Lewis JM, Kwong BY, Schpero W, et al. Acute upregulation of an NKG2D ligand promotes rapid reorganization of a local immune compartment with pleiotropic effects on carcinogenesis. Nat Immunol (2008) 9:146-54. doi:10.1038/ni1556

101. Erlandsson MC, Jonsson CA, Islander U, Ohlsson CH, Carlsten H. Oestrogen receptor specificity in oestradiol-mediated effects on B lymphopoiesis and immunoglobulin production in male mice. Immunology (2003) 108:346-51. doi:10.1046/j.1365-2567.2003.01599.x

102. Phalke SP, Chiplunkar SV. Activation status of $\gamma \delta \mathrm{T}$ cells dictates their effect on osteoclast generation and bone resorption. Bone Rep (2015) 3:95-103. doi:10.1016/j.bonr.2015.10.004

103. Pappalardo A, Thompson K. Activated $\gamma \delta \mathrm{T}$ cells inhibit osteoclast differentiation and resorptive activity in vitro. Clin Exp Immunol (2003) 174:281-91. doi:10.1111/cei.12165

104. Kalyan S, Quabius ES, Wiltfang JHM, Kabelitz D. Can peripheral blood $\Upsilon \delta \mathrm{T}$ cells predict osteonecrosis of the jaw? An immunological perspective on the adverse drug effects of aminobisphosphonate therapy. J Bone Miner Res (2013) 28:728-35. doi:10.1002/jbmr.1769

105. Lieberman SM, Evans AM, Han B, Takaki T, Vinnitskaya Y, Caldwell JA, et al. Identification of the beta cell antigen targeted by a prevalent population of pathogenic CD8+ T cells in autoimmune diabetes. Proc Natl Acad Sci U S A (2003) 100:8384-8. doi:10.1073/pnas.0932778100

106. Kotake S, Udagawa N, Takahashi N, Matsuzaki K, Itoh $\mathrm{K}$, Ishiyama $\mathrm{S}$, et al. IL-17 in synovial fluids from patients with rheumatoid arthritis is a potent stimulator of osteoclastogenesis. J Clin Invest (1999) 103:1345-52. doi:10.1172/JCI5703

107. Polanczyk MJ, Carson BD, Subramanian S, Afentoulis M, Vandenbark AA, Ziegler SF, et al. Estrogen drives expansion of the $\mathrm{CD} 4^{+} \mathrm{CD} 25^{+}$regulatory T cell compartment. J Immunol (2004) 173:2227-30. doi:10.4049/jimmunol. 173.4.2227

108. Buchwald ZS, Kiesel JR, Yang C, DiPaolo R, Novack DV, Aurora R. Osteoclast-induced Foxp3+ CD8 T-cells limit bone loss in mice. Bone (2013) 56:163-73. doi:10.1016/j.bone.2013.05.024

109. Glowacki AJ, Yoshizawa S, Jhunjhunwala S, Vieira AE, Garlet GP, Sfeir C, et al. Prevention of inflammation mediated bone loss in murine and canine periodontal disease via recruitment of regulatory lymphocytes. Proc Nat Acad Sci U S A (2013) 110:18525-30. doi:10.1073/pnas.1302829110

110. Zaiss MM, Frey B, Hess A, Zwerina J, Luther J, Nimmerjahn F, et al. Regulatory $\mathrm{T}$ cells protect from local and systemic bone destruction in arthritis. J Immunol (2010) 184:7238-46. doi:10.4049/jimmunol.0903841 
111. van Amelsfort JM, Jacobs KM, Bijlsma JW, Lafeber FP, Taams LS. CD4+ $\mathrm{CD} 25+$ regulatory $\mathrm{T}$ cells in rheumatoid arthritis: differences in the presence, phenotype, and function between peripheral blood and synovial fluid. Arthritis Rheum (2004) 50:2775-85. doi:10.1002/art.20499

112. Boskey AL. Bone composition: relationship to bone fragility and antiosteoporotic drug effects. Bonekey Rep (2013) 4:1-11. doi:10.1038/bonekey. 2013.181

113. Yousf H, Tomar GB, Srivastava RK. Probiotics and bone health: it takes GUTS to improve bone density. Int J Immunother Cancer Res (2015) 1(1): 018-022. doi:10.17352/2455-8591.000005

114. Li JY, Chassaing B, Tyagi AM, Vaccaro C, Luo T, Adams J, et al. Sex steroid deficiency associated bone loss is microbiota dependent and prevented by probiotics. J Clin Invest (2016) 126:1-15. doi:10.1172/JCI86062

115. Mangashetti LS, Khapli SM, Wani MR. IL-4 inhibits bone-resorbing activity of mature osteoclasts by affecting NF-kappa B and Ca2+ signaling. J Immunol (2005) 175:917-25. doi:10.4049/jimmunol.175.2.917

116. Yun TJ, Chaudhary PM, Shu GL, Frazer JK, Ewings MK, Schwartz SM, et al. OPG/FDCR-1, a TNF receptor family member, is expressed in lymphoid cells and is up-regulated by ligating CD40. J Immunol (1998) 161:6113-21.

117. Wing K, Yamaguchi T, Sakaguchi S. Cell-autonomous and non-autonomous roles of CTLA-4 in immune regulation. Trends Immunol (2011) 32:428-33. doi:10.1016/j.it.2011.06.002

118. Arboleya L, Castañeda S. Osteoimmunology: the study of the relationship between the immune system and bone tissue. Reumatol Clin (2013) 9:303-15. doi:10.1016/j.reuma.2013.02.008
119. Sims NA, Green JR, Glatt M, Schlict S, Martin TJ, Gillespie MT, et al. Targeting osteoclasts with zoledronic acid prevents bone destruction in collageninduced arthritis. Arthritis Rheum (2004) 50:2338-46. doi:10.1002/art.20382

120. Woodward J. Regulation of haematopoietic progenitor cell proliferation and survival. Cell Adh Migr (2010) 4(1):4-6. doi:10.4161/cam.4.1.10106

121. Adamopoulos IE, Bowman EP. Immune regulation of bone loss by Th17 cells. Arthritis Res Ther (2008) 5:225. doi:10.1186/ar2502

122. Harrington LE, Mangan PR, Weaver CT. Expanding the effector CD4 T-cell repertoire: the Th17 lineage. Curr Opin Immunol (2006) 18:349-56. doi:10.1016/j.coi.2006.03.017

123. Boyce BF, Xing L. Functions of RANKL/RANK/OPG in bone modeling and remodeling. Arch Biochem Biophys (2008) 473:139-46. doi:10.1016/j. abb.2008.03.018

124. Martin TJ. Osteoblast-derived PTHrP is a physiological regulator of bone formation. J Clin Invest (2005) 115:2322-4. doi:10.1172/JCI26239

Conflict of Interest Statement: The authors declare that the research was conducted in the absence of any commercial or financial relationships that could be construed as a potential conflict of interest.

Copyright (c) 2018 Srivastava, Dar and Mishra. This is an open-access article distributed under the terms of the Creative Commons Attribution License (CC BY). The use, distribution or reproduction in other forums is permitted, provided the original author(s) and the copyright owner are credited and that the original publication in this journal is cited, in accordance with accepted academic practice. No use, distribution or reproduction is permitted which does not comply with these terms. 